\title{
Phytoprotection
}

\section{Bacterial leaf spot, a new disease of lettuce in Quebec caused by Xanthomonas campestris pv. vitians}

\section{Toussaint}

Volume 80, numéro 2, 1999

URI : https://id.erudit.org/iderudit/706187ar

DOI : https://doi.org/10.7202/706187ar

Aller au sommaire du numéro

Éditeur(s)

Société de protection des plantes du Québec (SPPQ)l

ISSN

0031-9511 (imprimé)

1710-1603 (numérique)

Découvrir la revue

Citer cet article

Toussaint, V. (1999). Bacterial leaf spot, a new disease of lettuce in Quebec caused by Xanthomonas campestris pv. vitians. Phytoprotection, 80(2), 121-125. https://doi.org/10.7202/706187ar d'utilisation que vous pouvez consulter en ligne. 


\title{
Bacterial leaf spot, a new disease of lettuce in Quebec caused by Xanthomonas campestris pv. vitians
}

\author{
Vicky Toussaint
}

Department of Plant Science, Macdonald Campus, McGill University, 21111 Lakeshore, Ste-Anne-de Bellevue, Quebec, Canada H9X 3V9 and Agriculture and Agri-Food Canada, CRDH, 430 Gouin Blvd., St-Jean-sur-Richelieu, Quebec, Canada J3B 3E6

\section{PHYTOPROTECTION 80: 121-125}

Bacterial leaf spot of lettuce (BLSL) was reported for the first time in 1918 in the United States (Brown 1918). Since this first mention, the disease has been observed in different parts of the world including New York State (Burkholder 1954), Australia (Harrison 1963), California (Schroth et al. 1964; Umesh et al. 1996), Natal (India) (Wallis and Joubert 1972), New Zealand (Boesewinkel 1977), France (Allex and Rat 1990), Italy (Pennisi and Pane 1990), Florida (Pernezny et al. 1995), and Ohio (Sahin and Miller 1997). In Quebec, BLSL was observed for the first time in 1994 and a severe outbreak occurred in 1996 (Toussaint et al. 1998b). Losses reached up to $100 \%$ in some lettuce fields south-west of Montreal. The disease is now observed sporadically in the different lettuce production areas of Quebec.

In most of the cases in Quebec, BLSL of lettuce was observed on Romaine types. However, in 1998, the disease was also observed on Crisphead cultivars. In the United States, the disease is present on both Romaine and Crisphead cultivars (Pernezny et al. 1995; Sahin and Miller 1997). In France, the disease is mainly observed on Butterhead cultivars (Allex and Rat 1990).

\section{DESCRIPTION OF SYMPTOMS}

In the development of BLSL, the first apparent symptoms are water-soaked lesions at the margin of the leaves, which are noticeable only when the leaves are wet. Sometimes, these symptoms can also be observed on lettuce transplants in the greenhouse mainly on cotyledons. These water-soaked lesions collapse and appear almost transparent with a dark-brown coloration. When the disease progresses, lesions appear on the midrib of the leaves. The plant tissue around these lesions will turn light green followed by a yellowing of the entire leaves. When more than $50 \%$ of the leaf is affected, the leaf rapidly dies. The symptoms of BLSL are limited to leaves and have never been observed on stems or roots. When symptoms are restricted to the older leaves, these leaves can be removed at harvest and yield losses remain low. However, if the environmental conditions are favourable, the disease will progress to the heart of the plant, rendering the plant unmarketable. In cases of severe outbreaks, economic losses are important as an entire field can be

Note du rédacteur : le texte ci-dessus est présenté tel que soumis / Editor's note : the above text is presented as submitted. 
destroyed. From our experience, it has been observed that lettuces with BLSL symptoms are more susceptible to Botrytis cinerea, Sclerotinia sclerotiorum and Rhizoctonia solani. BLSL alone will rarely kill a plant.

\section{THE PATHOGEN}

BLSL is caused by Xanthomonas campestris pv. vitians (Brown) Dye. This bacterium is an aerobic Gram negative non-sporulating rod with one polar flagellum. Its optimal growth temperature in vitro is $28^{\circ} \mathrm{C}$. Contrasting with several other pathovars of Xanthomonas campestris, $X$. campestris pv. vitians does not hydrolyse starch.

According to the descriptive chart of the Society of American Bacteriologists, the organism was originally named Bacterium vitians (Brown 1918). Later, the name was changed to $X$. vitians (Brown) based on the classification of phytopathogenic bacteria (Dowson 1939). In 1974, Dye reclassified the genus Xanthomonas including; the pathogen responsible for bacterial leaf spot was then named $X$. campestris. pv. vitians (Dye and Lelliot 1974). In 1995, Vauterin et al. reclassified the genus Xanthomonas based on DNA homology. Strains of $X$. campestris pv. vitians were divided into two species: $X$. hortorum pv. vitians and $X$. axonopodis pv. vitians. However, only the type strain (ATCC19320) was included in the taxon $X$. axonopodis pv. vitians (Vauterin et al. 1995). All the other strains tested were classified as $X$. hortorum pv. vitians. This recent reclassification is still not accepted by the scientific community and recent literature still identify the pathogen as $X$. campestris pv. vitians (Pernezny et al. 1995; Sahin and Miller 1997; Sahin et al. 1997; Toussaint et al. 1998b; Umesh et al. 1996). To avoid confusion, and until evidence on the classification of the pathogen is confirmed, the name of $X$. carnpestris pv. vitians will be used throughout this communication.

In the BIOLOG database (version 3.7), the strains of $X$. campestris pv. vitians are classified in one of three types, A,
$B$, and $C$. The BIOLOG system identifies bacteria based on respiratory activity in the presence of different nutrients $(95$ nutrients). Characterisation of 30 strains of $X$. c. pv. vitians from Ohio by fatty acid methyl ester (FAME) analysis, protein electrophoresis, the BIOLOG GN microplate assay, indirect ELISA with a set of eight monoclonal antibodies (MAbs), amylolytic and pectolytic activity, and pathogenicity tests resulted in three groups, A, B, and C. Group A included only the reference strain LMG937 (ATCC19320), group B represented $17 \%$ of the 30 strains tested and group $\mathrm{C}$, a new group according to authors, included $83 \%$ of the strains tested (Sahin et al. 1997). In our identification based on BIOLOG system of strains from Quebec, Florida, Greece, Spain, and France, $57 \%$ of the strains were identified as $X$. campestris pv. vitians type $\mathrm{C}, 20 \%$ as $X$. campestris pv. carotae, and $23 \%$ as other identifications (Toussaint et al. 1998b). For the latter strains, the identification should be interpreted with care because some strains of $X$. campestris pv. vitians grow slowly, and consequently, the purple colour that develops in BIOLOG microplate during respiration is not strong enough in some wells to be detected. This can result in a wrong identification. These limitations of the BIOLOG system must be considered in the characterisation of bacterial strains.

\section{EPIDEMIOLOGY}

BLSL is observed under warm, humid and rainy environmental conditions. These weather requirements explain why the disease is rarely observed during the spring and in September in Quebec, but occurs more frequently in July and August, when the climate is propitious to the development of the disease. This disease is thought to be seed borne, but trials done to re-isolate the pathogenic bacteria from commercial lots of seed failed (Ohata et al. 1982; Umesh et al. 1996). However, it has been proven that it was possible to produce contaminated seed from contaminated plants (Sahin and Miller 1997; Umesh et al. 1996). 


\section{Dispersion of the bacteria in the greenhouse}

Wellman-Desbiens (1998) showed that a large number of seedlings in greenhouse can be contaminated by overhead irrigation. In her experiments, infected plants were produced from seed contaminated with a rifampicinresistant strain of $X$. campestris $\mathrm{pv}$. vitians. An infection focus composed of six contaminated plants was placed at one end of a greenhouse table containing 12000 non-contaminated lettuce seedlings. The seedlings were watered by overhead irrigation once a day and the dispersion of the bacteria was followed by imprints of lettuce leaves on a medium supplemented with rifampicin. Wellman-Desbiens (1998) demonstrated that after only 7 days, two-third of the seedlings were contaminated. Therefore, only a few contaminated seeds in a greenhouse lettuce transplant production would be enough to contaminate a large number of seedlings before the transplantation in the field. This might explain some of the recent outbreaks of BLSL.

\section{ECOLOGY}

$X$. campestris pv. vitians can survive as an epiphyte on leaf surfaces before inducing symptoms. Scanning electron microscopy of asymptomatic lettuce leaves contaminated by the pathogenic bacteria showed the presence of the bacteria at the surface of the leaf. Moreover, the pathogenic bacteria were recovered from asymptomatic lettuce leaves by dilution plating after leaves were macerated in phosphate buffer.

When the first symptoms appear on a leaf, a total of $10^{7} \mathrm{CFU} \mathrm{cm} \mathrm{cm}^{-2}$ of leaf can be recovered. However, even if the disease progresses on a leaf, no more than

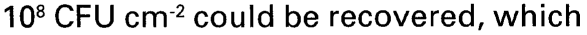
probably corresponds to the leaf carrying capacity. The limit in bacterial population could be due to a lack of nutrients or/and the amount of available space on the leaf (Blakeman and Brodie 1977; Derridj 1996; Fokkema 1984).

The population of $X$. campestris pv. vitians is highly dependent of the environmental conditions. During the days following a heavy rain or cool temperatures, a decrease of the bacterial population is observed (Toussaint et al. 1999b). However, the bacterial population has the capacity to re-establish itself rapidly when the environment becomes favourable again.

\section{CONTROL OF BLSL}

There are no bactericides that are recommended in the "Répertoire des traitements de protection des cultures" from Conseil des productions végétales du Québec for bacterial disease of lettuce. Pesticides allowed on other vegetables for control of bacterial diseases were tested for the control of bacterial leaf spot of lettuce. The most efficient treatments reduce disease severity by only $50 \%$ of that observed on non-treated plants (Carisse 1997; Carisse et al. 1999; Toussaint et al. 1998a, 1999a). Moreover, the use of some copper bactericides caused symptoms of phytotoxicity on lettuce plants.

For controlling bacterial leaf spot of lettuce, different approaches must be considered. An integrated disease management program should include the use of resistant cultivars of lettuce, seed treatments, an early detection of the bacterium on seedlings, and a biological and/or chemical control to reduce the pathogenic bacterial population in greenhouses.

\section{Susceptibility of cultivars}

Romaine, butterhead, crisphead, and green leaf types were tested for their susceptibility to BLSL. The Romaine types were the most susceptible types followed by the crisphead. However, within a same lettuce type, differences were observed among. For instance, in Butterheads, the cultivar Bella Green was highly susceptible and the cultivar Optima showed a low disease severity. Nevertheless, symptoms of BLSL were observed in all cultivars tested, but the green leaf types were the least susceptible (Carisse et al. 1999).

\section{Seed treatments}

Different seed treatments were tested for disinfecting contaminated seeds. Most of these treatments significantly 
reduced the incidence of contaminated seed. The most efficient treatment was $1 \%$ of sodium hypochlorite for a soaking time of 5 to $20 \mathrm{~min}$. However, treatments using dry heat or hot water for more than $1 \mathrm{~h}$ reduced significantly the seed germination as compared to the untreated seeds (Carisse et al. 1999).

\section{Detection, and chemical and biological control}

Considering the results obtained by Wellman-Desbiens (1998), showing that the pathogenic bacteria could be spread rapidly to a large greenhouse surface when overhead irrigation is used, it becomes important to develop a diagnostic test for early detection of the bacteria. If $X$. campestris pv. vitians is detected on seedlings before transplantation, the transplants could be destroyed or chemical and/or biological control could be applied to reduce the pathogenic bacterial population below the threshold for disease development.

\section{CONCLUSION}

In conclusion, $X$. campestris $\mathrm{pv}$. vitians can survive as an epiphyte on lettuce plant without showing symptoms. Consequently, it is difficult for seed manufacturers to produce uncontaminated seeds without a very sensitive detection test. Hence, like most bacterial diseases, prophylactic measures and integrated pest management must be favoured for the disease control.

\section{ACKNOWLEDGMENTS}

The author thanks all the mernbers of the working group on BLSL: Odile Carisse from Agriculture and Agri-Food Canada, Cindy E. Morris from the INRA of Avignon, France, Carole Beaulieu from Sherbrooke University, Elisabeth W.-Desbiens and Chantal Tellier, both graduate students.

\section{REFERENCES}

Allex, D., and B. Rat. 1990. Les bactérioses des salades : un problème omniprésent. PHM Rev. Hortic. 310 : 45-50.

Blakeman, J.P., and I.D.S. Brodie. 1977. Competition for nutrients between epiphytic microorganisms and germination of spores of plant pathogens on beetroot leaves. Physiol. Plant Pathol. 10 : 29-42.

Boesewinkel, H.J. 1977. A new disease of lettuce. New. Zeal. J. Agric. Res. 2.

Brown, N.A. 1918. Some bacterial diseases of lettuce. J. Agric. Res. $13: 367-388$.

Burkholder, W.H. 1954. Three bacteria pathogenic on head lettuce in New York State. Phytopathology 44 : 592-596.

Carisse, 0. 1997. Essais de produits bactéricides pour la répression de la nécrose marginale de la laitue (Xanthomonas sp. pv. vitians) in Journées horticoles provinciales, décembre 1997, Sherrington, Quebec, Canada.

Carisse, O., A. Ouimet, V. Toussaint, and V. Philion. 1999. Evaluation of the effect of seed treatments, bactericides and cultivars on bacterial leaf spot of lettuce caused by Xanthomonas campestris pv. vitians. Plant Dis. (in press).

Derridj, S. 1996. Nutrients on the leaf surface. Pages 25-42 in C. E. Morris, P. C. Nicot, and C. Nguyen-The (eds.), Aerial plant surface microbiology. Plenum Press, New York.

Dowson, W.J. 1939. On the systematic position and generic names of the Gram negative bacterial plant pathogens. Zentralbl. Bakteriol. Parasitenkd. Infektionskr. Hyg. Abt. 100 : 177-193.

Dye, D.W., and R.A. Lelliot. 1974. Genus II. Xanthomonas. Pages 199-210 in R.E.B. and N.E. Gibbons (eds.), Bergey's manual of determinative bacteriology, 8th ed. Williams \& Wilkins, Baltimore.

Fokkema, N.J. 1984. Competition for endogenous and exogenous nutrients between Sporoblomyces roseus and Cochliobolus sativus. Can. J. Bot. 62 : 2463-2468.

Harrison, D.E. 1963. Leaf spot and dry rot of lettuce caused by Xanthomonas vitians (Brown) Dowson. Aust. J. Agric. Res. 14 : 778-784.

Ohata, K., S. Serizawa, K. Azegami, and A. Shirata. 1982. Possibility of seed transmission of Xanthomonas campestris pv. vitians, the pathogen of bacterial spot of lettuce. Bull. Nat. Inst. Agric. Sci. $36: 81$ 88. 
Pennisi, A.M., and A. Pane. 1990. Gravi epidemie di Xanthomonas campestris pv. vitians (Brown) Dye su lattuga in Sicilia. Inf. Fitopatol. 4 : 56-58.

Pernezny, K., R.N. Raid, R.E. Stall, N.C. Hodge, and J. Collins. 1995. An outbreak of bacterial spot of lettuce in Florida caused by Xanthomonas campestris pv. vitians. Plant Dis. 79 : 359-360.

Sahin, F., and S.A. Miller. 1997. Identification of the bacterial leaf spot pathogen of lettuce, Xanthomonas campestris pv. vitians, in Ohio, and assessment of cultivar resistance and seed treatment. Plant Dis. $81: 1443-1446$.

Sahin, F., P.A. Abbasi, and S.A. Miller. 1997. Variation among strains of Xanthomonas campestris pv. vitians isolated from lettuce in Ohio. Phytopathology 87 : S84.

Schroth, M.N., J.P. Thompson, R. Bardin, and $A$. Greathead. 1964. A new disease in California... bacterial spot of lettuce. Calif. Agric. : 2-3.

Toussaint, V., O. Carisse, and V. Philion. 1998a. Repression of bacterial leaf spot of lettuce in the field. Trial Report. Agriculture and Agri-Food Canada, St-Jeansur-Richelieu, Quebec, Canada.

Toussaint, V., C.E. Morris, and O. Carisse. 1998b. Identification, resistance to antibiotics and utilization of carbon sources by Xanthomonas campestris pv. vitians strains isolated from different lettuce growing areas in 7th International Congress of Plant Pathology, Edinburgh, Scotland.
Toussaint, V., O. Carisse, and V. Philion. 1999a. Repression of bacterial leaf spot of lettuce in the field. Trial Report. Agriculture and Agri-Food Canada, St-Jeansur-Richelieu, Quebec, Canada.

Toussaint, V., C.E. Morris, and O. Carisse. 1999b. Effect of environmental conditions on the development of bacterial leaf spot symptoms and bacterial pathogenic population (in preparation).

Umesh, K.C., S.T. Koike, and R.L. Gilbertson. 1996. Association of Xanthomonas campestris pv. vitians with lettuce seed. Phytopathology 86 : S3.

Vauterin, L., B. Hoste, K. Kersters, and J. Swings. 1995. Reclassification of Xanthomonas. Int. J. Syst. Bacteriol. 45 : 472489.

Wallis, F.M., and J.J. Joubert. 1972. Bacterial leafspot of lettuce in Natal. Phytolactica 4 : 137-138.

Wellman-Desbiens, E. 1998. Études sur les sources de contamination par les bactéries responsables de la nervation noire du chou et de la nécrose marginale de la laitue. Master Thesis, Université de Sherbrooke, Sherbrooke, Québec, Canada. 